\title{
First report of the family Zelinkaderidae (Kinorhyncha: Cyclorhagida) for the Caribbean Sea, with the description of a new species of Triodontoderes Sørensen and Rho, 2009 and an identification key for the family
}

\author{
Cepeda Diego ${ }^{1,{ }^{*}}$, Sanchez Nuria ${ }^{1,2}$, Pardos Fernando ${ }^{1}$
}

\begin{abstract}
${ }^{1}$ Departamento de Biodiversidad, Ecología y Evolución, Facultad de Ciencias Biológicas, Universidad Complutense de Madrid, José Antonio Novais St. 12, 28040 Madrid, Spain

2 Laboratoire Environnement Profond, Institut Français de Recherche pour l'Exploitation de la Mer

(IFREMER), Centre Bretagne - ZI de la Pointe du Diable, CS 10070 - 29280 Plouzané, France
\end{abstract}

*Corresponding author : Diego Cepeda, email address : diegocepeda@ucm.es

\begin{abstract}
:
A new species of Kinorhyncha, Triodontoderes lagahoo sp. nov., is described from Tobago Island, Caribbean Sea (western Atlantic Ocean) from a coastal, sandy habitat using both light and scanning electron microscopy. The species is characterized by the presence of middorsal acicular spines on segments $1-11$ (that on segment 10 crenulated in males), laterodorsal crenulated spines on segment 10 only in males, lateroventral acicular spines on segments 3-4 and 6-8 (lateroventral spines also on segment 10 in females), lateroventral cuspidate spines on segments 5 and 9 , lateral accessory acicular spines on segments 5 and 9 , lateral accessory cuspidate spines on segment 8 , ventrolateral acicular spines on segment 2 and ventrolateral cuspidate spines on segment 2 . Females furthermore possess short papillae in ventrolateral position on segment 8 and ventromedial position on segment 9 . The absence of cuspidate spines in lateral accessory position on segment 6 easily distinguishes $T$. lagahoo sp. nov. from the single known congener, $T$. anulap. Moreover, also the arrangement of female papillae and sensory spots differ between the species. The finding of a new species of Triodontoderes in the Caribbean Sea is the first report of the genus for American waters and the Atlantic Ocean since its original description. Additionally, a dichotomous key for identification of the family Zelinkaderidae to species level, as well as systematic remarks on some morphological characters of the new species are included herein.
\end{abstract}

Keywords : Kinorhynchs, Biodiversity, Meiofauna, Morphology, Taxonomy, Triodontoderes lagahoo sp. nov. 


\section{Introduction}

Kinorhynchs are small-sized, holobenthic, free-living, marine invertebrates that inhabit sandy and muddy sediments (Higgins and Thiel, 1988; Neuhaus, 2013; Sørensen and Pardos, 2008). Currently, the phylum comprises near 300 species distributed worldwide and arranged in two classes, Allomalorhagida and Cyclorhagida (Sørensen et al. 2015). The cyclorhagid family Zelinkaderidae was originally erected by Higgins (1990) to accommodate the newly described species Zelinkaderes floridensis Higgins, 1990 from Fort Pierce, Florida (western Atlantic Ocean) and the reassigned Cateria submersa (Gerlach, 1969), originally described from the North Sea. Not much later, Zelinkaderes klepali Bauer-Nebelsick, 1995 was described from the Red Sea and, more recently, Zelinkaderes brightae Sørensen et al., 2007 also from Fort Pierce. Two years later, the second genus of the family was erected with the description of Triodontoderes anulap Sørensen and Rho, 2009 from the Chuuk Islands, Micronesia (western Pacific Ocean). Finally, Zelinkaderes yong Altenburger et al., 2015 was described from the Korean Peninsula (western Pacific Ocean).

Zelinkaderid kinorhynchs are morphologically characterized by having an introvert with one ring of spinoscalids followed by three or four regular scalids rings, fourteen or sixteen distally tripartite placids, trunk vermiform and conspicuously circular in cross-section, at least segments 5 to 11 composed of a single tergal plate with midventral joint, acicular spines present in dorsal and lateral positions, cuspidate spines present in lateral position on some segments, segment 11 with lateral terminal, lateral terminal accessory and midterminal spines, at least some large and oval sensory spots with two pores in the anterior body region, scale-like cuticular hairs medially depressed and males with crenulated spines on segment 10 (Sørensen and Rho, 2009). In the present contribution, a new Triodontoderes species, Triodontoderes lagahoo sp. nov., is described from Tobago Island (Caribbean Sea) using light and scanning electron microscopes. This finding is the first report of the genus for American waters and the western Atlantic Ocean since its original description from the Chuuk Archipelago, Pacific Ocean (Sørensen and Rho, 2009). Additionally, a key to species level identification for Zelinkaderidae is included.

\section{Material and methods}


70 Specimens of Triodontoderes lagahoo sp. nov. were collected at Tyrrel's Bay, Tobago

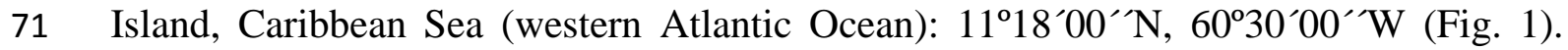

72 The Archipelago of Trinidad and Tobago is situated at the verge of the Lesser Antilles

73 (Fig. 1) and is part of the so-called Southern Caribbean marine ecoregion. Sampling was

74

75 originally done on 13 May 1991 by Dr R. P. Higgins using a meiobenthic dredge (Higgins and Thiel, 1988) at $5 \mathrm{~m}$ depth in very fine sand. After sampling, meiofauna was extracted from sediment using the bubble and blot method defined by Higgins (1964). Meiofaunal specimens were fixed in $4 \%$ formalin, preserved in Carosafe ${ }^{\circledR}$ and deposited in unsorted vials at the Smithsonian National Museum of Natural History (NMNH), Washington.

The aforementioned vials were loaned to the authors for the present study. Fixed kinorhynchs were picked up under a Motic ${ }^{\circledR}$ SMZ-168 stereo zoom microscope with the help of an Irwin loop and washed with distilled water in order to remove formalin. For light microscopy (LM), specimens were dehydrated through a graded series of $25 \%$, $50 \%, 75 \%$ and $100 \%$ glycerin and finally mounted on a glass slide in Fluoromount $\mathrm{G}^{\circledR}$ sealed with Depex ${ }^{\circledR}$. Mounted specimens were studied and photographed using an Olympus ${ }^{\circledR}$ BX51-P microscope equipped with differential interference contrast (DIC) optics and an Olympus ${ }^{\circledR}$ DP-70 camera. Morphological measurements were obtained with Olympus cellSens ${ }^{\circledR}$ software. For scanning electron microscopy (SEM), specimens were transferred to $70 \%$ ethanol and then progressively dehydrated through a series of $80 \%, 90 \%, 95 \%$ and $100 \%$ ethanol. Specimens were sonically cleaned during 5-7 s. Hexamethyldisilazane (HMDS) was used for chemical drying through a HMDS-ethanol series. Specimens were coated with gold and mounted on aluminium stubs to be examined with a JSM 6335-F JEOL SEM at the ICTS Centro Nacional de Microscopía Electrónica (Complutense University of Madrid, Spain). Line drawings, images and plates plates composition were done using Adobe ${ }^{\circledR}$ Photoshop CC-2014 and Illustrator CC-2014 software.

\section{Results}

\section{Taxonomic account}

Class Cyclorhagida (Zelinka, 1896) Sørensen et al., 2015 
101 Order Kentrorhagata Sørensen et al., 2015

102 Family Zelinkaderidae Higgins, 1990

103 Genus Triodontoderes Sørensen and Rho, 2009

104 Triodontoderes lagahoo sp. nov.

105 (Figs. 2-6 and Tabs. 1-3)

106 The species was registered in Zoobank under: zoobank.org:pub:7699F0E0-3F1B-451C-

107 8E43-EB548773D1C0.

\subsection{Type material}

Holotype, adult female, collected on 13 May 1991 at Tyrrel's Bay, Tobago Island, western Atlantic Ocean: $11^{\circ} 18^{\prime} 00^{\prime \prime} \mathrm{N}, 60^{\circ} 30^{\prime} 00^{\prime \prime} \mathrm{W}$ at $5 \mathrm{~m}$ depth in very fine sand; mounted in Fluoromount $\mathrm{G}^{\circledR}$, deposited at NMHN under accession number: XXXXX. Paratypes, seven adult males and four adult females, all of them with same collecting data as holotype, mounted in Fluoromount $G^{\circledR}$, deposited at NMHN under accession numbers: XXXXX-XXXXX.

\subsection{Non-type material}

Five additional specimens with same collecting data as holotype and paratypes, mounted for SEM, deposited at the Invertebrates Collection of the Meiofaunal Laboratory at the Universidad Complutense de Madrid (UCM), Spain.

\subsection{Diagnosis}

Triodontoderes with middorsal acicular spines on segments 1-11 (that on segment 10 crenulated in males), laterodorsal crenulated spines on segment 10 only in males, lateroventral acicular spines on segments 3-4 and 6-8 (lateroventral spines also on segment 10 in females), lateroventral cuspidate spines on segments 5 and 9, lateral accessory acicular spines on segments 5 and 9, lateral accessory cuspidate spines on segment 8 , ventrolateral acicular spines on segment 2 and ventrolateral cuspidate spines on segment 2. Females with short papillae in ventrolateral position on segment 8 and ventromedial position on segment 9 . Neck and trunk segments superficially covered by small, scale-like, medially depressed cuticular hairs arranged in slightly irregular longitudinal bands. Primary pectinate fringe short on segment 1 , strongly serrated with 
130 bifid tips on the remaining trunk segments. Dorsal extensions of segment 11 elongated,

131 distally pointed, horn-like; ventral extensions of segment 11 short, wide, distally

132 rounded.

133

134

\subsection{Etymology}

The species is named after the mythical shapeshifting monster "Lagahoo" (also known as "Ligahoo" or "Lugarhou") from the folklore of Trinidad and Tobago, the location where the species was found. According to the legend, Lagahoo can shapeshift into various creatures, which resembles the different trunk shapes reported herein for the species.

\subsection{Description}

See Tables 1-2 for measurements and dimensions, and Table 3 for summary of acicular, crenulated and cuspidate spines, papillae and sensory spots location.

Head with narrow, retractable mouth cone and introvert with five rings plus an extra ring of trichoscalids attached to the neck (Figs. 3 and 4A-H). Mouth cone presumably with four rings of oral styles, incompletely observed (Fig. 3). Ring of helioscalids and the first ring of inner oral styles (rings -03 and -02) barely visible in the examined specimens. Second ring of inner oral styles (ring -01) with ten styles (Fig. 3). Observed inner oral styles of ring - 01 composed of a single unit, with a trapezoidal, enlarged base bearing a short fringe and a triangular, hook-like, inwards-pointed, distal tip (Fig. 4C). Ring 00 with nine equally-sized outer oral styles that morphologically resemble the inner oral styles but much longer and flexible at their distal tips, with a fringe and paired spines arising from their bases (Figs. 3, 4C-D and 6B). Outer oral styles composed of a single unit, located anterior to each introvert sector, except in the middorsal section 6 where a style is missing (Fig. 3). Triangular, cuticular thickenings flanking the outer oral styles' bases (Fig. 4D). Posterior part of mouth cone elongated, forming a long tube (Fig. 4A-B).

Heads were only everted in the holotype (mounted for LM) and one paratype, (mounted for SEM), which disabled precise examination of the arrangement and morphology of scalids in the remaining specimens. Ring 01 with ten primary spinoscalids (Fig. 3) composed of a basal sheath and a distal elongated end-piece; basal sheath equipped with a median dense fringe with long tips (Fig. 4E-F). Tips of the 
161 fringe slightly protrude outwards when the introvert is retracted inside the trunk, and lay on top of the primary spinoscalids when the introvert is completely everted (Fig. 4F). Ring 02 with fifteen regular-sized scalids, arranged as two in the odd-numbered sectors and one in the even-numbered sectors (Figs. 3 and 4G-H). Scalids on this and remaining rings are composed of a basal sheath and a distal, elongated, hook-like end-piece (Fig. 4G-H). Ring 03 with fifteen regular-sized scalids, arranged as one in the odd-numbered sectors and two in the even-numbered sectors (Figs. 3 and 4G-H). Ring 04 similar to ring 02 (Figs. 3 and 4G-H). Ring 05 similar to ring 03 (Figs. 3 and 4G-H). The location of scalids in rings $01-05$ follows a strict pattern around the introvert, and each sector carries six scalids, five following a quincunx arrangement plus a single scalid that appears anterior (in even-numbered sectors) or posterior (in odd-numbered sectors) (Figs. 3 and 4G-H).

Neck with fourteen inconspicuous, elongated, distally tripartite, soft placids of uniform size; placids are fused with the segment 1 and a transverse articulation between placids and segment 1 is missing (Figs. 2A-B, 4A-B and 6A, C). Fourteen small, triangular trichoscalids attached to the neck, whose occurrence is directly associated with the placids position (Figs. 3 and 4E). Trichoscalid plates absent.

Trunk vermiform, circular in cross-section, spindle-shaped, composed of eleven segments (Figs. 2A-B, 4A-B and 6A). Body outline variable from longer and slender to shorter and chubby (Figs. 2A-C and 4A-B, J-L). Cuticle along the whole trunk thin, soft and flexible, making the intersegmental junctions barely visible. First trunk segment with one tergal and one sternal plate (Fig. 2A-B); segments 2-4 with one tergal and two sternal plates with lateroventral and midventral joints (Fig. 2A-B); remaining segments with a single tergal plate with midventral joint (Fig. 2A-B, D-E). Segment 1 fused with the neck, without distinct articulation (Figs. 2A-B, 5A and 6A, C). Neck and all trunk segments superficially covered by small, scale-like, medially depressed cuticular hairs arranged in slightly irregular longitudinal bands (Figs. 2A-B, D-E and 6D, G, I); cuticular hairs absent at ventrolateral and ventromedial regions of trunk (Fig. 2B, E). Trunk segments with longitudinal folds on the dorsal and lateral sides that are most certainly a fixation artefact (Figs. 2A, C, D, 4A-B, 5A-B, D-E, G-H and 6A). Posterior margin of segments straight, with long primary pectinate fringes (except that of segment 1 that is conspicuously shorter); primary pectinate fringes with very weak serration on first segment, with strong serration and bifid tips on remaining segments (Figs. 2A-B, 
194 D-E and 4I). Secondary pectinate fringes on segments 2-11 less conspicuous than primary ones but also long, ventrally extending near the posterior margin of segment, also serrated and with bifid tips (Figs. 2A-B, D-E and 4I).

Segment 1 with a small, very short, extremely flexible acicular spine in middorsal position (Figs. 2A and 5A). Acicular spines on this and following segments are composed of a single flexible, elongated piece with pointed tip that basally articulates in a swollen cuticular thickening (Figs. 2A-B, D-E, 4I, 5A-K and 6A, D-F, $\mathrm{H}, \mathrm{J}$ ); basal swollen articulation of acicular spines with paired cuticular protuberances that flank the spine (Figs. 2A and 5A). Paired sensory spots in paradorsal position, on top of the protuberances beside the spine's basal articulation (Figs. 2A and similar to 6D). Sensory spots on this and most following segments are composed of an oval patch of numerous micropapillae surrounding a central pore (similar to $6 \mathrm{G}$ ).

Segment 2 with acicular spine in middorsal position (Figs. 2A and 5A); paired small, very short, extremely flexible acicular spines in ventrolateral position (Figs. 2B and 5B). Paired cuspidate spines also in ventrolateral position, but located between tergosternal junction and acicular spine (Figs. 2B and 5B). Cuspidate spines on this and following segments are composed of a single syringe-like piece with broadened base, of which the latter constitutes more than $50 \%$ of the spine dimension, basally articulated (Figs. 2B, E, 5B, E, H and 6E). Paired sensory spots in paradorsal position, similar to those of the precedent segment (Figs. 2A and 5A).

Segment 3 with acicular spine in middorsal position and paired acicular spines in lateroventral position (Figs. 2A-B and 5A-B). Paired sensory spots in paradorsal, laterodorsal and ventrolateral positions (Figs. 2A-B and 5A-B).

Segment 4 with acicular spine in middorsal position and paired acicular spines in lateroventral position (Figs. 2A-B and 5D-E). Paired sensory spots in paradorsal, laterodorsal, midlateral and ventrolateral positions (Figs. 2A-B, 5D and 6G). Midlateral sensory spots on this and following segments are composed of an oval patch of numerous micropapillae surrounding two pores (similar to Fig. 6I).

Segment 5 with acicular spine in middorsal position and paired acicular spines in lateral accessory position (Figs. 2A-B, 5D-E and 6E); paired cuspidate spines in lateroventral position (Figs. 2B, 5E and 6E). Paired sensory spots in paradorsal, laterodorsal, midlateral and ventrolateral positions (Figs. 2A-B, 5D-E and 6G). 
Segment 6 with arrangement of spines and sensory spots similar to segment 4

227 (Figs. 2A-B, 5D-E and 6F, I).

Segment 7 with arrangement of spines and sensory spots similar to segments 4 and 6 (Figs. 2A-B, 5D, H and 6F).

Segment 8 with acicular spine in middorsal position and paired acicular spines in lateroventral position (Figs. 2A-B, D-E, 5G-H and 6D, F); paired cuspidate spines in lateral accessory position (Figs. 2B, E and 5H). Paired sensory spots in paradorsal, laterodorsal and midlateral positions (Figs. 2A-B, D-E, 5G and 6D). Females with paired, small papillae in ventrolateral position (Figs. 2B and 5H); papillae on this and following segment are rounded areas with a minute tubular structure carrying a basal collar of short, flexible hairs.

Segment 9 with acicular spine in middorsal position and paired acicular spines in lateral accessory position (Figs. 2A-B, D-E and 5G-H); paired cuspidate spines in lateroventral position (Figs. 2B, E and 5H). Paired sensory spots in paradorsal, subdorsal and laterodorsal positions (Figs. 2A, D and 5G). Females with paired, small papillae in ventromedial position (Fig. 2B and 5H).

Segment 10 differing between males and females. Males with an unpaired, crenulated spine in middorsal position and paired, crenulated spines in laterodorsal position (Figs. 2D, 5J and 6H). Females with an unpaired, acicular spine in middorsal position and paired acicular spines in lateroventral position (Figs. 2A-B and 5G-H). Females with paired, large, strongly cuticularized, rounded gonopores at the intersegmental junction between segments 10 and 11 (Fig. 5I). Both males and females with paired sensory spots in paradorsal and subdorsal positions (Figs. 2A, D and 5G).

Segment 11 tapering to the base of the midterminal spine, with acicular spine in middorsal position and paired lateral terminal and lateral terminal accessory spines (Figs. 2A-B, D-E, 5C, F, G, I-K and 6A, J). Tergal plate of segment 11 carrying two elongated, distally pointed, horn-like dorsal extensions (Figs. 2A, D, 5F and 6J) as well as two short, wide, distally rounded ventral extensions (Figs. 2B, E and 5I). Paired sensory spots arranged on top of the paired cuticular protuberances beside the middorsal spine's basal articulation, in paradorsal position (Figs. 2A, D, 5G-J and 6J). Two pairs 
258 pairs of sensory spots in laterodorsal position, one near the base of the dorsal cuticular 259 extensions, another near the basal insertion of the lateral terminal spines (Figs. 2A, D 260 and 6J), barely visible under LM.

\section{Discussion}

\subsection{Remarks on morphological features}

264

Triodontoderes lagahoo sp. nov. fits well into the genus Triodontoderes by the combination of the following characters: oral styles of mouth cone composed of a single piece; neck composed of fourteen soft, elongated, inconspicuous, equally-sized, distally tripartite placids fused with segment 1 ; neck and trunk with small, scale-like, medially depressed cuticular hairs irregularly arranged in longitudinal bands; segment 1 with one tergal and one sternal plate, segments 2-4 with one tergal and two sternal plates and remaining segments with a single tergal plate with midventral joint; unpaired middorsal spines on all trunk segments; segment 2 with paired, small, very flexible acicular spines in ventrolateral position plus paired cuspidate spines also in ventrolateral position; segments 3-9 with lateral acicular and/or cuspidate spines; males with middorsal and paired laterodorsal crenulated spines on segment 10; females with paired, lateroventral acicular spines on segment 10 and paired ventral papillae on some segment from 7 to 9; segment 11 with midterminal, lateral terminal and lateral terminal accessory spines (Sørensen and Rho, 2009).

Until now, the genus Triodontoderes was composed of a single species, $T$. anulap, from the Chuuk Archipelago, Micronesia, western Pacific Ocean (Sørensen and Rho, 2009). The main morphological discrepancies between the two congeners are summarized in Table 4. Both species may be easily distinguished by their patterns of spines, female papillae and sensory spots. Triodontoderes anulap is characterized by having paired cuspidate spines in lateral accessory position on segment 6 (Sørensen and Rho, 2009), absent in T. lagahoo sp. nov. Moreover, females of T. anulap have paired papillae in ventrolateral position on segments 7-8 and in ventromedial position on segment 9 (Sørensen and Rho, 2009), while females of T. lagahoo sp. nov. possess papillae in ventrolateral position only on segment 8 and in ventromedial position on segment 9. Additionally, the main differences between both species in sensory spot are the presence of paired sensory spots in laterodorsal position on segments 3-9 and 11 in 
$290 T$. lagahoo sp. nov. (only on segment 10 in T. anulap), in midlateral position on 291 segments 4-8 (only on segment 2 in $T$. anulap) and in ventrolateral positions on

292

293

294

295

296

297

298

299

300

301

302

303

304

305

306

307

308

309

310

311

312

313

314

315

316

317

318

319

320

321

322 segments 3-7 (displaced to ventromedial position and on segments 4, 6-8 and 10-11 in T. anulap) (see Sørensen and Rho, 2009, for complete sensory spots arrangement of $T$. anulap).

Another morphological discrepancy between both species refer to the trunk pectinate fringes and cuticular hairs. Triodontoderes anulap only possesses serrated posterior margin of segments with long pectinate fringes on segments 7-11 (Sørensen and Rho, 2009), whereas T. lagahoo sp. nov. has serrated posterior margin of segments and long pectinate fringes on segments 2-11. Moreover, T. anulap is characterized by having several wavy secondary pectinate fringes composed of tiny scales mixed with slightly longer aciculae from segment 2 (Sørensen and Rho, 2009), while T. lagahoo sp. nov. has a single straight secondary pectinate fringe strongly serrated and with bifid tips, also from segment 2. Finally, T. anulap has cuticular hairs arranged all over the integument (Sørensen and Rho, 2009), whereas those of T. lagahoo sp. nov. are absent at ventrolateral and ventromedial regions of trunk.

A striking morphological feature of T. lagahoo sp. nov. is the presence of two different body outlines. Of the seventeen examined specimens, twelve belong to the slender body outline and five to the chubby one. Both females and males were found in the two different body outlines. Specimens with short and chubby body outline possess the same number of trunk segments and arrangement of cuticular structures than those with long and slender body outline (Fig. 4J). Moreover, these specimens also possess developed gonads and, in case of females, conspicuous gonopores (Fig. 4L). Though the abundance of the slender specimens were higher than that of the chubby ones, the latter body outline could be an artefact of the fixation process. As both types of body outlines were found in the vial containing non-mounted animals (Fig. 4K), the chubby shape is not result of the mounting process for LM. Nevertheless, two possibilities must be considered. On the one hand, the species may have the ability of kindly modifying its body outline due to the soft cuticle that characterizes this genus. This could be related to the proposed hypothesis by Yamasaki (this issue) of thin-cuticle body kinorhynchs, as this kind of cuticle would allow the animal being more flexible to seep through sediment interstices more easily and absorbing physical damage when sand grains are disturbed. On the other hand, the chubby specimens may correspond to the latest 
323 juvenile stages of the species. Though both chubby females and males were found with

324 completely developed gonads, and gonopores in case of females (Fig. 4L), the latest

325 juvenile stages of kinorhynchs often begin to develop gonads (Neuhaus, 2013).

\subsection{Remarks on systematic features}

327 Triodontoderes, together with the genus Zelinkaderes, belongs to the family 328 Zelinkaderidae, whose monophyly was supported by a total-evidence analysis 329 (Sørensen et al. 2015). This family is morphologically characterized by possessing an introvert with one ring of primary spinoscalids followed by three or four rings of regular scalids, a trunk conspicuously circular in cross-section, at least segments 5 to 10 composed of a single tergal plate with midventral joint, acicular spines present in dorsal and lateral positions, cuspidate spines present on some segments, a segment 11 with lateral terminal, lateral terminal accessory and midterminal spines, at least some large, oval sensory spots with two pores in the anterior trunk region, scale-like cuticular hairs with a medial depression and male sexually dimorphic crenulated spines on segment 10 (Sørensen and Rho, 2009).

The introvert of Zelinkaderidae is characterized by the reduction of, at least, one ring of scalids. Regular scalids are completely absent on rings $02-03$ in Z. brightae and Z. klepali (Bauer-Nebelsick, 1995; Sørensen et al. 2007); on ring 06 in T. anulap and T. lagahoo sp. nov. (Sørensen and Rho, 2009; this paper); on rings 05-06, odd sectors of ring 03 and even sectors of ring 02 in Z. floridensis (Higgins, 1990); and on ring 02, even sectors of ring 06 and odd sectors of ring 03 in Z. yong (Altenburger et al. 2015). In summary, species of Zelinkaderes generally shows a strong reduction of the introvert scalids, as this reduction involves more than a single ring, whereas Triodontoderes only shows scalid reduction in the last ring. Additionally, Zelinkaderes seems to show more variability in the scalid arrangement (Sørensen et al. 2007) than the genus Triodontoderes, with identical disposition of scalids in the two known species (Sørensen and Rho, 2009; this paper). The only other cyclorhagid genus with a considerably lower number of scalids is Cateria Gerlach, 1956, that, besides the ten primary spinoscalids, possesses 35 regular scalids (Herranz et al., this issue; Neuhaus and Kegel, 2015). Furthermore, a newly described genus of Franciscideridae also possesses a reduction in the number of scalids, lacking these structures in ring 06 and the even-numbered sectors of ring 05 (Yamasaki, this issue). It seems that Cateria, Triodontoderes and the new genus of Franciscideridae lost its more posterior scalid 
356 rings (Herranz et al., this issue; Sørensen and Rho, 2009; Yamasaki, this issue), whereas

357 Zelinkaderes reduced the scalids in its more anterior rings (Altenburger et al. 2015;

358 Sørensen et al. 2007). The reduction of scalids could have occurred independently in the

359 four genera, as also proposed by Herranz et al. (this issue). However, this hypothesis

360 cannot be tested until a more complete systematic analysis of Kentrorhagata is

361 performed.

362 The presence of distally tripartite placids seems also to be a synapomorphic 363 feature of the family Zelinkaderidae (Sørensen and Rho, 2009), with the exception of $Z$. 364 yong that has very reduced placids (Altenburger et al. 2015). Both species of 365 Triodontoderes also share the former feature (Sørensen and Rho, 2009; this paper). 366 According to the most recent phylogenetic analysis (Sørensen et al. 2015), it is likely 367 that the plesiomorphic condition for placid morphology in Zelinkaderidae is the 368 possession of distally tripartite placids. Then, Z. yong would have suffered a reversion 369 of the character state through the placid reduction as an autapomorphy of the species. 370 Again, this hypothesis cannot be tested until more morphological, and especially molecular phylogenetic data is available for the whole family.

One of the important morphological differences between species of Triodontoderes and Zelinkaderes is the number and arrangement of both acicular and cuspidate spines. The former genus is characterized by having middorsal acicular spines along all trunk segments (Sørensen and Rho, 2009; this paper), whereas the latter has middorsal spines on segments 4, 6 and 8-11 (Sørensen et al. 2007). Additionally, lateral acicular and/or cuspidate spines are present on segment 2 and 4-9 in Zelinkaderes (Altenburger et al. 2015; Bauer-Nebelsick, 1995; Higgins, 1990; Sørensen et al. 2007), while they are present in at least one sex on segments 2-10 in Triodontoderes (Sørensen and Rho, 2009; this paper). Thus, a greater number of dorsal and lateral spines characterizes the genus Triodontoderes within the family Zelinkaderidae. However, it is still too early to infer an evolutionary trend towards increasing or decreasing the number of spines in Zelinkaderidae.

\subsection{Key to species of Zelinkaderidae}

1. Segment 1 composed of one tergal and one sternal plate; segments 2 to 4 composed of one tergal and two sternal plates; segments 5 to 11 composed of a single plate with midventral joint; neck consisting of 14 distally tripartite placids; middorsal spines 
388 present on all trunk segments; cuticular hairs irregularly arranged in scattered bands ...

3892 (genus Triodontoderes)

390 - Segments 1 to 2 composed of one closed cuticular ring; segments 3 to 11 composed of 391 a single plate with midventral joint; neck consisting of 16 entire or distally tripartite 392 placids; middorsal spines present on segments 4, 6 and 8 to 11; cuticular hairs regularly 393 arranged in longitudinal bands ...3 (genus Zelinkaderes)

394 2. Lateral accessory cuspidate spines present on segment 6; female, sexually dimorphic 395 papillae present in ventrolateral position on segments 7 to 8 and in ventromedial 396 position on segment 9; long, conspicuous pectinate fringes on segments 7 to $11 \ldots T$. 397 anulap

398 - Lateral accessory cuspidate spines absent on segment 6; female, sexually dimorphic 399 papillae present in ventrolateral position on segment 8 and in ventromedial position on 400 segment 9; long, conspicuous pectinate fringes on segments 2 to $11 \ldots$ T. lagahoo sp. 401 nov.

4023 . Spines present in various lateral positions on segment $2 \ldots 4$

403

- Spines absent on segment 2 ... Z. floridensis

404

4. Lateroventral or lateral accessory acicular spines present on segment $9 \ldots 5$

405

- Lateroventral or lateral accessory acicular spines absent on segment 9 ... Z. yong

406

5. Cuspidate spines present in lateral series on segments 4 and $6 \ldots 6$

407

- Cuspidate spines absent in lateral series on segments 4 and 6 ... Z. klepali

408

6. Cuspidate spines present in lateroventral position on segment 7... Z. submersus

409

- Cuspidate spines absent in lateroventral position on segment 7 ... Z. brightae

410

411

\section{References}

412 Altenburger, A., Rho, H.S., Chang, C.Y., Sørensen, M.V., 2015. Zelinkaderes yong sp. 413 nov. from Korea - the first recording of Zelinkaderes (Kinorhyncha: Cyclorhagida) in 414 Asia. Zool. Stud. 54: 25. https://doi.org/10.1186/s4055-014-0103-6. 
415 Bauer-Nebelsick, M., 1995. Zelinkaderes klepali sp. n., from shallow water sands of the

416 Red Sea. Ann. Naturhist. Mus. Wien 97(B): 57-74.

417 Gerlach, S.A., 1969. Cateria submersa sp. n., ein cryptorhager Kinorhynch aus dem 418 sublitoralen Mesopsammal der Nordsee. Veröff. Inst. Meeresf. Bremerhaven 12: 161419168.

420 Herranz, M., Di Domenico, M., Sørensen, M.V., Leander, B.S., this issue. The 421 enigmatic kinorhynch Cateria styx Gerlach, 1956 - a sticky son of a beach. Zool. Anz., 422 this issue.

423 Higgins, R.P., 1964. Three new kinorhynchs from the North Carolina Coast. Bull. Mar. 424 Sci. 14: 479-493.

425 Higgins, R.P., 1990. Zelinkaderidae, a new family of cyclorhagid Kinorhyncha. 426 Smithson. Contrib. Zool. 500: 1-26. https://doi.org/10.5479/si.00810282.500.

427 Higgins, R.P., Thiel, H., 1988. Introduction to the study of meiofauna, first ed. 428 Smithsonian Institution Press, Washington D.C.

429 Neuhaus, B., 2013. Kinorhyncha (=Echinodera), in: Schmidt-Rhaesa, A. (Ed.), 430 Handbook of Zoology, Gastrotricha, Cycloneuralia and Gnathifera, Volume 1 431 Nematomorpha, Priapula, Kinorhyncha, Loricifera. De Gruyter, Hamburg, pp. 181-350.

432 Neuhaus, B., Kegel, A., 2015. Redescription of Cateria gerlachi (Kinorhyncha, 433 Cyclorhagida) from Sri Lanka and of C. styx from Brazil, with notes on C. gerlachi 434 from India and C. styx from Chile, and the ground pattern of the genus. Zootaxa 3965, $4351-77$.

436 Sørensen, M.V., Dal Zotto, M., Rho, H.S., Herranz, M., Sánchez, N., Pardos, F., 437 Yamasaki, H., 2015. Phylogeny of Kinorhyncha based on morphology and two 438 molecular loci. PLoS ONE $\quad$ 10(7), 0133440. 439 https://doi.org/10.1371/journal.pone.0133440.

440 Sørensen, M.V., Heiner, I., Ziemer, O., Neuhaus, B., 2007. Tubulideres seminoli gen. et 441 sp. nov. and Zelinkaderes brightae sp. nov. (Kinorhyncha, Cyclorhagida) from Florida. 442 Helgol. Mar. Res. 61: 247-265. https://doi.org/10.1007/s10152-007-0073-8. 
443 Sørensen, M.V., Pardos, F., 2008. Kinorhynch systematics and biology - An

444 introduction to the study of kinorhynchs, inclusive identification keys to the genera.

445 Meiofauna Marina 16: 21-73.

446 Sørensen, M.V, Rho, H.S., 2009. Triodontoderes anulap gen. et sp. nov. - a new

447 cyclorhagid kinorhynch genus and species from Micronesia. J. Mar. Biol. Assoc. U. K.

448 89(6): 1269-1279. https://doi.org/10.1017/S0025315409000526.

449 Yamasaki, H., this issue. Gracilideres mawatarii, a new genus and species of 450 Franciscideridae (Allomalorhagida: Kinorhyncha) from Japan with morphological 451 comparison of head characters, and special attention to thin-cuticle body of

452 Kinorhyncha in relation to adaptation to interstitial environment. Zool. Anz., this issue.

453 Zelinka, C., 1896. Demonstration der Tafeln der Echinoderes - Monographie. Verh. 454 Dtsch. Zool. Ges. 6: 197-199.

\section{ACKNOWLEDGEMENTS}

457 We would like to thank Dr Jon Norenburg and Kathryn Ahlfeld for loaning the material 458 that made the present study possible.

\section{FUNDING SOURCES}

460 Cepeda was supported by a predoctoral fellowship of the Complutense University of 461 Madrid (CT27/16-CT28/16).

The authors declare no conflicts of interest. 
470

471

472

473

474

475

476

477

478

479 TABLES

480 Table 1. Measurements of body size, lateral terminal, lateral terminal accessory and 481 midterminal spines of adult Triodontoderes lagahoo sp. nov., including number of 482 measured specimens $(n)$, mean of data and standard deviation (SD). There were no 483 remarkable differences in sizes or dimensions between the two sexes. Abbreviations:

484 LTAS, lateral terminal accessory spine; LTS, lateral terminal spine; MTS, midterminal 485 spine; $\mathrm{S}$, segments lengths (number after $\mathrm{S}$ indicates the corresponding segment); TL, 486 total length of trunk.

\begin{tabular}{lll}
\hline Character & Range & Mean $($ SD; $\boldsymbol{n})$ \\
\hline TL $(\mu \mathrm{m})$ & $319.0-540.2$ & $428.0(62.0 ; 12)$ \\
S1 $(\mu \mathrm{m})$ & $35.5-72.8$ & $51.1(13.1 ; 12)$ \\
S2 $(\mu \mathrm{m})$ & $21.2-57.4$ & $43.1(12.0 ; 12)$ \\
S3 $(\mu \mathrm{m})$ & $25.4-62.9$ & $47.4(11.3 ; 12)$ \\
S4 $(\mu \mathrm{m})$ & $29.8-63.8$ & $52.3(11.9 ; 12)$ \\
S5 $(\mu \mathrm{m})$ & $29.4-67.2$ & $55.4(12.8 ; 12)$ \\
S6 $(\mu \mathrm{m})$ & $39.5-63.7$ & $52.1(7.8 ; 12)$ \\
S7 $(\mu \mathrm{m})$ & $37.5-65.9$ & $53.4(8.8 ; 12)$ \\
S8 $(\mu \mathrm{m})$ & $47.8-76.0$ & $56.6(12.0 ; 12)$ \\
S9 $(\mu \mathrm{m})$ & $31.5-76.2$ & $58.4(12.4 ; 12)$ \\
S10 $(\mu \mathrm{m})$ & $34.3-71.2$ & $56.7(11.9 ; 12)$ \\
S11 $(\mu \mathrm{m})$ & $26.0-51.1$ & $43.8(11.6 ; 12)$
\end{tabular}




\section{ACCEPTED MANUSCRIPT}

$\begin{array}{lll}\text { LTS }(\mu \mathrm{m}) & 52.8-78.8 & 60.8(6.9 ; 12) \\ \text { LTS/TL }(\%) & 10.6-21.5 & 14.5(3.1 ; 12) \\ \text { LTAS }(\mu \mathrm{m}) & 33.7-42.4 & 39.7(3.8 ; 12) \\ \text { LTAS/TL }(\%) & 8.2-13.3 & 9.5(1.9 ; 12) \\ \text { LTAS/LTS }(\%) & 55.4-74.4 & 65.6(4.5 ; 12) \\ \text { MTS }(\mu \mathrm{m}) & 117.6-288.2 & 214.8(51.7 ; 9) \\ \text { MTS/TL }(\mu \mathrm{m}) & 27.8-72.3 & 39.5(27.5 ; 9)\end{array}$

487

488 Table 2. Measurements of middorsal, laterodorsal, lateral accessory and lateroventral 489 spines of adult Triodontoderes lagahoo sp. nov., including number of measured 490 specimens $(n)$, mean of data and standard deviation (SD). Abbreviations: ac, acicular 491 (spine); cr, crenulated (spine); cu, cuspidate (spine); f, female condition of sexually 492 dimorphic character; LAS, lateral accessory spine; LDS, laterodorsal spine; LVS, 493 lateroventral spine; $\mathrm{m}$, male condition of sexually dimorphic character; MDS, middorsal 494 spine.

\begin{tabular}{|c|c|c|}
\hline Character & Range & Mean $(S D ; n)$ \\
\hline MDS 1 (ac) $(\mu \mathrm{m})$ & $5.0-10.5$ & $7.5(1.8 ; 11)$ \\
\hline MDS $2(\mathrm{ac})(\mu \mathrm{m})$ & $14.3-34.2$ & $24.9(7.6 ; 12)$ \\
\hline MDS $3(\mathrm{ac})(\mu \mathrm{m})$ & $24.5-53.2$ & $38.9(7.4 ; 11)$ \\
\hline MDS $4(\mathrm{ac})(\mu \mathrm{m})$ & $32.5-57.7$ & $46.1(8.6 ; 11)$ \\
\hline MDS $5(\mathrm{ac})(\mu \mathrm{m})$ & $37.6-60.5$ & $48.9(7.9 ; 12)$ \\
\hline $\operatorname{MDS} 6(\mathrm{ac})(\mu \mathrm{m})$ & $42.5-64.5$ & $53.3(8.4 ; 12)$ \\
\hline MDS 7 (ac) $(\mu \mathrm{m})$ & $41.3-71.9$ & $58.6(9.0 ; 12)$ \\
\hline MDS $8(\mathrm{ac})(\mu \mathrm{m})$ & $47.9-71.1$ & $60.8(7.9 ; 12)$ \\
\hline MDS $9(\mathrm{ac})(\mu \mathrm{m})$ & $39.3-73.4$ & $59.9(10.5 ; 11)$ \\
\hline $\operatorname{MDS} 10(\mathrm{cr}, \mathrm{m} ; \mathrm{ac}, \mathrm{f})(\mu \mathrm{m})$ & $22.3-65.9$ & $42.8(13.2 ; 12)$ \\
\hline MDS $11(\mathrm{ac})(\mu \mathrm{m})$ & $25.4-51.7$ & $46.0(7.6 ; 12)$ \\
\hline LDS $10(\mathrm{cr}, \mathrm{m})(\mu \mathrm{m})$ & $26.1-34.8$ & $31.6(3.3 ; 7)$ \\
\hline VLS $2(\mathrm{ac})(\mu \mathrm{m})$ & $11.4-22.0$ & $16.1(4.9 ; 12)$ \\
\hline $\operatorname{VLS} 2(\mathrm{cu})(\mu \mathrm{m})$ & $13.6-24.2$ & $18.3(5.2 ; 12)$ \\
\hline LVS $3(\mathrm{ac})(\mu \mathrm{m})$ & $19.9-50.0$ & $34.0(8.8 ; 12)$ \\
\hline LVS $4(\mathrm{ac})(\mu \mathrm{m})$ & $31.0-55.6$ & $41.9(7.6 ; 11)$ \\
\hline LVS 5 (cu) $(\mu \mathrm{m})$ & $18.8-27.4$ & $23.4(3.1 ; 12)$ \\
\hline LAS $5(\mathrm{ac})(\mu \mathrm{m})$ & $32.3-55.6$ & $43.2(8.4 ; 12)$ \\
\hline LVS $6(\mathrm{ac})(\mu \mathrm{m})$ & $36.1-56.1$ & $48.9(6.4 ; 12)$ \\
\hline LVS 7 (ac) $(\mu \mathrm{m})$ & $40.0-65.7$ & $54.8(8.6 ; 12)$ \\
\hline LVS $8(\mathrm{ac})(\mu \mathrm{m})$ & $38.2-47.5$ & $42.7(2.9 ; 12)$ \\
\hline LAS $8(\mathrm{cu})(\mu \mathrm{m})$ & $20.5-30.5$ & $26.0(3.5 ; 12)$ \\
\hline
\end{tabular}



$\operatorname{LVS} 9(\mathrm{cu})(\mu \mathrm{m})$
$22.5-31.7 \quad 28.2(2.5 ; 12)$
LAS $9(\mathrm{ac})(\mu \mathrm{m})$
$34.9-50.4$
$43.1(6.0 ; 12)$
LVS $10(\mathrm{ac}, \mathrm{f})(\mu \mathrm{m})$
$21.7-28.1$
$24.0(2.8 ; 5)$

495

496 Table 3. Summary of nature and arrangement of sensory spots, papillae and spines in

497 Triodontoderes lagahoo sp. nov. Abbreviations: ac, acicular spine; cr, crenulated spine;

$498 \mathrm{cu}$, cuspidate spine; f, female condition of sexually dimorphic character; LA, lateral

499 accessory; LD, laterodorsal; ltas, lateral terminal accessory spine; lts, lateral terminal

500 spine; LV, lateroventral; $\mathrm{m}$, male condition of sexually dimorphic character; MD,

501 middorsal; mt, midterminal spine; ML, midlateral; pa, papilla; PD, paradorsal; SD,

502 subdorsal; ss, sensory spot; ss3, type 3 sensory spot; VL, ventrolateral; VM, 503 ventromedial.

\begin{tabular}{|c|c|c|c|c|c|c|c|c|c|}
\hline Segment & MD & PD & SD & LD & ML & LA & $\mathbf{L V}$ & VL & VM \\
\hline 1 & $\mathrm{ac}$ & SS & & & & & & & \\
\hline 2 & ac & ss & & & & & & $\mathrm{cu}, \mathrm{ac}$ & \\
\hline 3 & $\mathrm{ac}$ & ss & & ss & & & $\mathrm{ac}$ & ss & \\
\hline 4 & $\mathrm{ac}$ & ss & & ss & ss & & $\mathrm{ac}$ & ss & \\
\hline 5 & $\mathrm{ac}$ & ss & & ss & ss & $\mathrm{ac}$ & $\mathrm{cu}$ & ss & \\
\hline 6 & $\mathrm{ac}$ & ss & & ss & ss & & $\mathrm{ac}$ & ss & \\
\hline 7 & $\mathrm{ac}$ & ss & & & ss & & $\mathrm{ac}$ & ss & \\
\hline 8 & $\mathrm{ac}$ & ss & & ss & ss & $\mathrm{cu}$ & $\mathrm{ac}$ & $\mathrm{pa}(\mathrm{f})$ & \\
\hline 9 & $\mathrm{ac}$ & ss & & ss & & $\mathrm{ac}$ & $\mathrm{cu}$ & & $\mathrm{pa}(\mathrm{f})$ \\
\hline 10 & $\operatorname{cr}(\mathrm{m}) / \mathrm{ac}(\mathrm{f})$ & ss & & $\operatorname{cr}(\mathrm{m})$ & & & $\mathrm{ac}(\mathrm{f})$ & & \\
\hline 11 & $\mathrm{ac}, \mathrm{mt}$ & ss & , ss 3 & Ss, ss & & ltas & lts & & \\
\hline
\end{tabular}

504

505 Table 4. Summary of main morphological differences between Triodontoderes anulap 506 and T. lagahoo sp. nov.

\begin{tabular}{lll}
\hline Character & T. anulap & T. lagahoo sp. nov. \\
\hline Cuspidate spines in lateral & Present & Absent \\
accessory position on segment 6 & & \\
Female papillae arrangement & Ventrolateral on segments 7-8 & Ventrolateral on segment 8 and \\
& and ventromedial on segment 9 & ventromedial on segment 9 \\
Laterodorsal sensory spots & Segment 10 & Segments 3-9 and 11 \\
Midlateral sensory spots & Segment 2 & Segments 4-8 \\
Ventral sensory spots & Ventromedial on segments 4, 6- & Ventrolateral on segments 3-7
\end{tabular}


Long and conspicuous trunk Segments 7-11

pectinate fringes

507

508

509

510

511

512

513

514

515

516

FIGURE LEGENDS

517 Fig. 1. Map showing the sampling locality on Tobago Island (Trinidad and Tobago),

518 Lesser Antilles, Caribbean Sea (western Atlantic Ocean).

519 Fig. 2. Line art illustrations of Triodontoderes lagahoo sp. nov. (A) Female, dorsal 520 overview; (B) Female, ventral overview; (C) Female, dorsal overview showing the fat

521 shape of the species; (D) Male, segments 8-11, dorsal overview; (E) Male, segments 8-

522 11, ventral overview. Abbreviations: de, dorsal extension (of segment 11); dpl, dorsal

523 placid; f, female condition of sexually dimorphic feature; go, gonopore; laac, lateral

524 accessory acicular spine; lacu, lateral accessory cuspidate spine; ldcr, laterodorsal

525 crenulated spine; ldss, laterodorsal sensory spot; ltas, lateral terminal accessory spine;

526 lts, lateral terminal spine; lvac, lateroventral acicular spine; lvcu, lateroventral cuspidate

527 spine; $\mathrm{m}$, male condition of sexually dimorphic feature; mdac, middorsal acicular spine;

528 mdcr, middorsal crenulated spine; mlss, midlateral sensory spot; mts, midterminal

529 spine; mvj, midventral junction; pdss, paradorsal sensory spot; ppf, primary pectinate

530 fringe; S, segment followed by number of corresponding segment; sdss, subdorsal

531 sensory spot; sdss3, subdorsal type 3 sensory spot; spf, secondary pectinate fringe; tsj,

532 tergo-sternal junction; ve, ventral extension (of segment 11); vlac, ventrolateral acicular

533 spine; vlcu, ventrolateral cuspidate spine; vlpa, ventrolateral papilla; vlss, ventrolateral

534 sensory spot; vmpa, ventromedial papilla; vpl, ventral placid. 
535 Fig. 3. Diagram of mouth cone, introvert and trichoscalids in Triodontoderes lagahoo

536 sp. nov., with indication of oral style, scalid and trichoscalid arrangement. The 537 outermost bold lines refers to the placids.

538 Fig. 4. Light micrographs (A-J, L) and stereomicroscope photo (K) showing trunk 539 overviews and details in the mouth cone, introvert and general cuticular trunk characters 540 of the female holotype NMNH XXXXX (A-I), a male paratype NMNH XXXXX (J), a 541 female paratype NMNH XXXXX (L) and non-mounted additional specimens (K) of 542 Triodontoderes lagahoo sp. nov. (A) Dorsal overview of trunk; (B) ventral overview of 543 trunk; (C) mouth cone, with detail of the last ring of inner oral styles (ring -01); (D) 544 mouth cone, with detail of the ring of outer oral styles (ring 00); (E) introvert, showing 545 the first ring of primary spinoscalids (ring 01) and trichoscalids; (F) detail of a primary 546 spinoscalid, showing the rigid spine that extends from its basal plate; $(\mathrm{G})$ sector 5 of 547 introvert, with detail of scalids of rings $02-05$; $(\mathrm{H})$ sector 6 of introvert, with detail of 548 scalids of rings 02-05; (I) midlateral and lateroventral regions on right half of tergal 549 plate of segments $8-10$, with detail of primary and secondary pectinate fringes; $(\mathrm{J})$ 550 ventral overview of a chubby body outline male; (K) slender body outline (right) and 551 chubby body outline (left) non-mounted specimens; (L) ventral view of segments 7-11 552 of a chubby body outline female, showing the gonads and the gonopores. 553 Abbreviations: bs, basal sheath; dp, distal piece; f, female condition of sexually 554 dimorphic character; g, gonad; go, gonopore; ios, inner oral style; oos, outer oral style; 555 ppf, primary pectinate fringe; psc, primary spinoscalid; r, ring; S; segment followed by 556 number of corresponding segment; sp, spine; sc, scalid; spf, secondary pectinate fringe; 557 tct, triangular cuticular thickening; ts, trichoscalid.

558 Fig. 5. Light micrographs showing details of cuticular trunk characters of female 559 holotype NMNH XXXXX (A-I, K) and male paratype NMNH XXXXX (J) of 560 Triodontoderes lagahoo sp. nov., with main focus on spines, sensory spots, sexually 561 dimorphic features and segment 11 cuticular extensions. (A) Dorsal view of segments 1562 3; (B) lateral view of right half of segments 2-3; (C) dorsal view of segment 11 , 563 showing the two pairs of type 3 sensory spots; (D) dorsal view of segments 4-7; (E) 564 lateral accessory to ventromedial regions on right half of tergal and sternal plates of 565 segments 4-6; (F) dorsal view of segment 11, showing the tergal extensions (in arrows); 566 (G) dorsal view of segments 8-11; $(\mathrm{H})$ lateral accessory to ventromedial regions on right 567 half of tergal plates of segments 7-10; (I) ventral view of segment 11, showing the 
568 sternal extensions (in arrows) and the female gonopores; $(\mathrm{J})$ lateral view of right half of

569 a male segment 11; $(\mathrm{K})$ ventral view of segment 11, showing the midterminal spine.

570 Abbreviations: f, female condition of sexually dimorphic character; go, gonopore; laac,

571 lateral accessory aciculate spine; lacu, lateral accessory cuspidate spine; ldcr,

572 laterodorsal crenulated spine; ltas, lateral terminal accessory spine; lts, lateral terminal

573 spine; lvac, lateroventral acicular spine; lvcu, lateroventral cuspidate spine; m, male

574 condition of sexually dimorphic character; mdac, middorsal acicular spine; mdcr,

575 middorsal crenulated spine; mts, midterminal spine; pa, papilla; vlac, ventrolateral

576 acicular spine; vlcu, ventrolateral cuspidate spine; sensory spots are marked as

577 continuous circles and papillae as dotted circles; numbers after spines indicate the

578 corresponding segment.

579 Fig. 6. Scanning electron micrographs showing general overview and details of the 580 cuticular trunk morphology of non-type specimens of Triodontoderes lagahoo sp. nov.

581 (A) Dorsal overview of trunk; (B) mouth cone, showing the outer oral styles; (C) dorsal 582 view of neck, showing the distally tripartite placids; (D) detail of middorsal spine of 583 segment 8 , showing the swollen cuticular thickenings of its basal articulation with the 584 paired paradorsal sensory spots; (E) lateroventral and lateral accessory regions on right 585 half of tergal plates of segment 5; (F) middorsal and paradorsal regions of tergal plates 586 of segments 6-8; (G) laterodorsal region on left half of tergal plates of segments 4-5; 587 (H) dorsal view of a male segment 10, showing the crenulated middorsal and 588 laterodorsal spines; (I) detail of midlateral sensory spot of segment 6; (J) lateral view of 589 left half of segment 11 tergal plate, showing all sensory spots on left side. 590 Abbreviations: de, dorsal extension (of segment 11); laac, lateral accessory acicular 591 spine; ldcr, laterodorsal crenulated spine; ldss, laterodorsal sensory spot; lvcu, 592 lateroventral cuspidate spine; m, male condition of sexually dimorphic character; mdac, 593 middorsal acicular spine; mdcr, middorsal crenulated spine; pdss, paradorsal sensory 594 spot; sdss3, subdorsal type 3sensory spot; sensory spots are marked as continuous 595 circles; numbers after spines indicate the corresponding segment. 


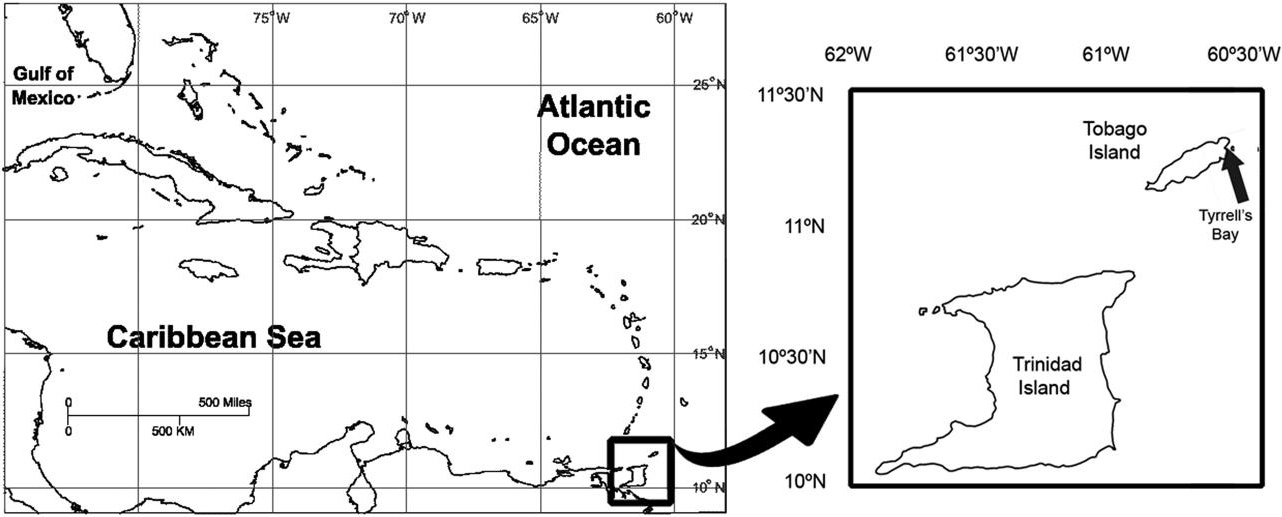



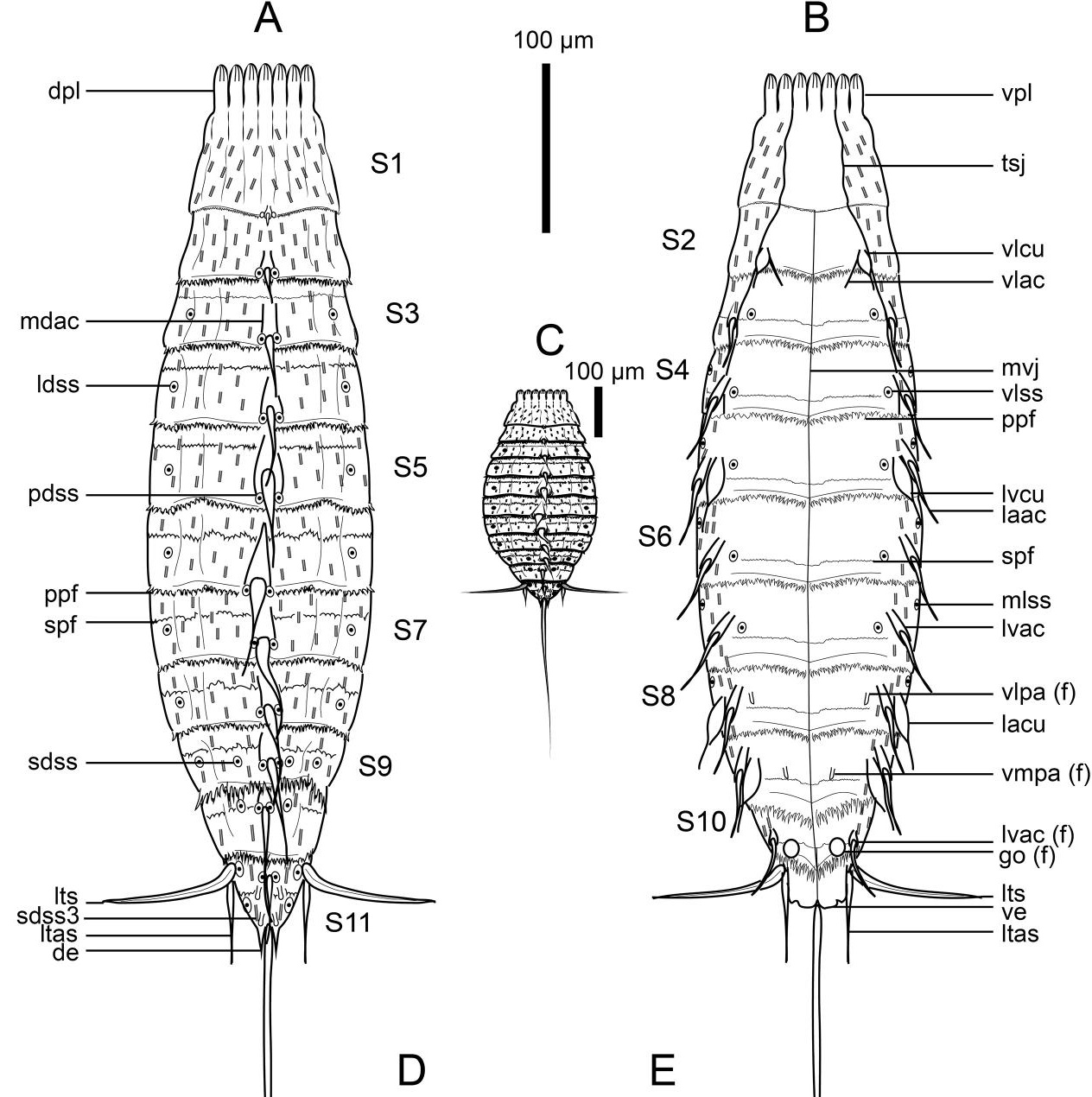
S6

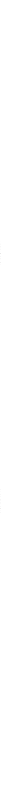

Oral style and scalid arrangement

By ring:

Ring -03: ? helioscalids

Ring -02: ? inner oral styles

Ring -01: 10 inner oral styles

Ring 00: 9 outer oral styles

Ring 01: 10 primary spinoscalids

Ring 02: 15 scalids

Ring 03: 15 scalids

Ring 04: 15 scalids

Ring 05: 15 scalids

Ring 06: /

Trichoscalid row: 14 trichoscalids

\section{By sector:}

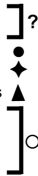

Odd sectors: 6 scalids

$$
0_{0}^{0} 0
$$

Even sectors: 6 scalids

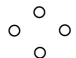





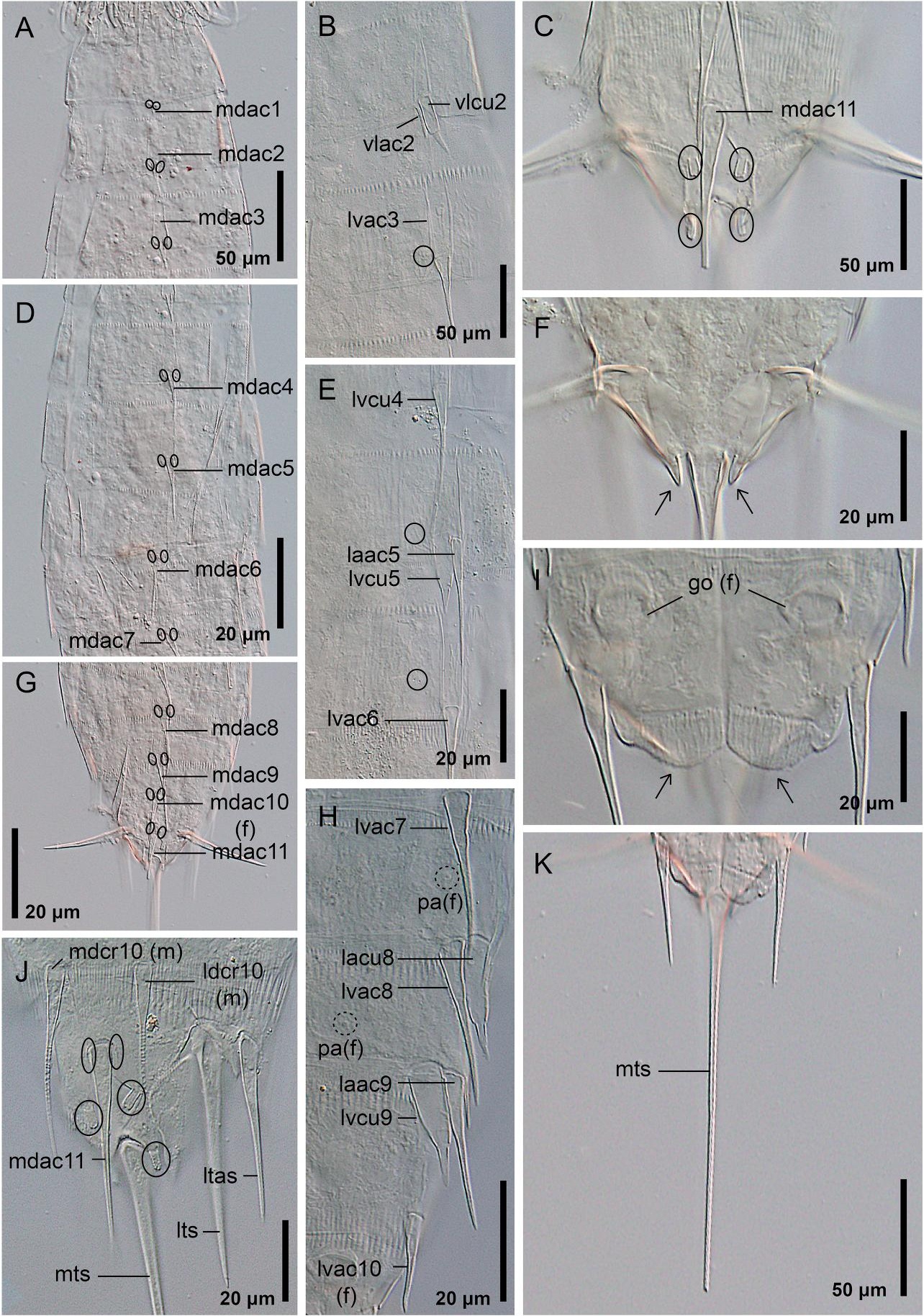




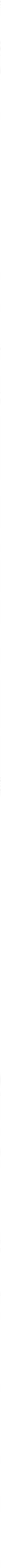

